\title{
Psychroflexus torquis gen. nov., sp. nov., a psychrophilic species from Antarctic sea ice, and reclassification of Flavobacterium gondwanense (Dobson et al. 1993) as Psychroflexus gondwanense gen. nov., comb. nov.
}

Antarctic CRC and School of

Agricultural Science, University of Tasmania, GPO Box 252-80, Hobart, Tasmania 7001, Australia

\author{
John P. Bowman, Sharee A. McCammon, Tom Lewis, \\ Jennifer H. Skerratt, Janelle L. Brown, David S. Nichols \\ and Tom A. McMeekin
}

Author for correspondence: John P. Bowman. Tel: +6136226 2776. Fax: +61362262642. e-mail: john.bowman@utas.edu.au
A group of sea-ice-derived psychrophilic bacterial strains possessing the unusual ability to synthesize the polyunsaturated fatty acids eicosapentaenoic acid $(20: 5 \omega 3)$ and arachidonic acid $(20: 4 \omega 6)$ belong to the Family Flavobacteriaceae (Flexibacter-Bacteroides-Flavobacterium phylum), according to $16 \mathrm{~S}$ rRNA sequence analysis. Surprisingly, the isolates were also found to cluster closely to the moderately halophilic and psychrotrophic species [Flavobacterium] gondwanense (sequence similarity 97.8-98.1\%). The wholecell fatty acid profiles of this group and [Flavobacterium] gondwanense were very similar and distinct from other related flavobacteria. The sea ice strains and [Flavobacterium] gondwanense differed substantially in terms of ecophysiology, possibly representing divergent adaptations to sympagic and planktonic marine habitats, respectively. Evidence based on phylogeny and fatty acid profiles supports the conclusion that the taxa are close relatives distinct from other bacterial groups. It is thus proposed that the sea ice strains represent a novel taxon designated Psychroflexus torquis gen. nov., sp. nov. (type strain ACAM 623') while [Flavobacterium] gondwanense becomes Psychroflexus gondwanense gen. nov., comb. nov.

Keywords: Psychroflexus gen. nov., Antarctica, polyunsaturated fatty acids, psychrophilic bacteria, halophilic bacteria

\section{INTRODUCTION}

A partitioning phenomenon has been observed to occur between the bacterial communities of sympagic (sea ice) and coastal pelagic environments of Antarctica. Sea ice diatom assemblages provide a niche for the proliferation of a wide variety of epiphytic and free-living psychrophilic bacteria (Bowman et al., 1997a, b). The reasons for this are not completely clear but are thought to be primarily due to nutrient concentration enhancement and increased availability of surfaces for colonization (Bowman et al., 1997b; Delille, 1996; Helmke \& Weyland, 1995; Priddle et al., 1996; Sullivan

Abbreviation: PUFA, polyunsaturated fatty acid.
\& Palmisano, 1984). Within the sea ice/seawater interface zone, especially areas with platelet ice populated heavily by ice diatoms, a number of psychrophilic, gasvacuolate bacteria have been isolated (Gosink \& Staley, 1995; Gosink et al., 1998; Irgens et al., 1996). Often sympagic (ice-dwelling) psychrophiles have fastidious growth requirements and only utilize a relatively narrow range of substrates (Bowman et al., 1997a). Many of these nutrients are probably derived from exudates of sea ice diatoms (Malinsky-Rushansky \& Legrand, 1996) and extensive bacterial colonization of the surfaces of various diatom species has been observed frequently (Sullivan \& Palmisano, 1984; Palmisano \& Garrison, 1993). By comparison, the reduction in the availability of organic compounds and lack of surfaces for colonization is at least partially responsible for the 
bacterioplanktonic community being mostly psychrotrophic, nutritionally versatile and non-exacting (Delille, 1996), but with a distinct capacity for cold adaptation (Christian \& Karl, 1995). In this context it is possible that within a single genus, species which inhabit each of these habitats may express substantially different ecophysiological traits, reflecting adaptations to their respective habitats. In this study a group of psychrophilic sea ice strains with the unusual capacity to form polyunsaturated fatty acids (PUFAs) (Nichols et al., 1997) were found to be closely related to the psychrotrophic, moderately halophilic, planktonic species [Flavobacterium] gondwanense (Dobson et al., 1993). The two taxa represent distinct species within a novel genus, Psychroflexus gen. nov. The ecophysiological differences between the species of Psychroflexus provide an example of the capacity of bacterial species to become highly adapted to a range of specific habitats but still retain common chemotaxonomic properties and phylogenetic relatedness.

\section{METHODS}

Cultivation of bacterial strains. The sea ice strains, including Polaribacter strains IC054, IC066 and 23-P, [Flectobacillus] glomeratus (brackets indicate species is generically misclassified), Gelidibacter algens, Psychroserpens burtonensis and 'Melosira-colonizing' strain IC166 were grown at $5-10^{\circ} \mathrm{C}$ on marine 2216 agar (Difco). [Flavobacterium] gondwanense, [Flavobacterium] salegens, [Cytophaga] latercula, [Cytophaga] lytica, [Cytophaga] marinoflava and [Flexibacter] maritimus were cultivated on marine 2216 agar at $20^{\circ} \mathrm{C}$. The sea ice isolates were preserved by freezing cell suspensions at $-80{ }^{\circ} \mathrm{C}$ in marine 2216 broth to which $30 \%$ (v/v) glycerol was added.

Phenotypic characterization. Most phenotypic tests used in the study have been described previously (Bowman et al., 1997 a c). Additional enzymic tests were performed using the following chromogenic substrates (Smibert \& Krieg, 1994): $p$-nitrophenyl $\alpha$-L-arabinopyranoside $(\alpha$-arabinosidase), $p$-nitrophenyl $\alpha$-L-fucopyranoside ( $\alpha$-fucosidase), $p$-nitrophenyl $\alpha$-D-galactopyranoside ( $\alpha$-galactosidase), $o$-nitrophenyl $\beta$-D-galactopyranoside (ONPG; $\beta$-galactosidase), $p$-nitrophenyl $\alpha$-D-glucopyranoside ( $\alpha$-glucosidase), $p$-nitrophenyl $\beta$-D-glucopyranoside ( $\beta$-glucosidase), $o$-nitrophenyl $\beta$-Dgalactopyranoside 6-phosphate (streptococcal $\beta$-galactosidase), $\quad p$-nitrophenyl $\beta$-D-glucuronide ( $\beta$-glucuronidase), $\alpha$-D-mannopyranoside ( $\alpha$-mannosidase) and $p$-nitrophenyl phosphate (alkaline phosphatase, in $0.4 \mathrm{M}$ glycine buffer, $\mathrm{pH} 10 \cdot 0)$.

Growth rate analysis. The temperature/growth rate response curve of strain ACAM $623^{\mathrm{T}}$ was determined in a temperature gradient incubator (Toyokagaku Sangyo). The temperature gradient ranged from 0 to $25^{\circ} \mathrm{C}$. Tubes containing $10 \mathrm{ml}$ marine 2216 broth, were inoculated with $0.5 \mathrm{ml}$ cells taken from late-exponential-phase cultures grown at $10^{\circ} \mathrm{C}$. Growth was measured by an increase in $\mathrm{OD}_{550}$ for up to $20 \mathrm{~d}$. Growth was considered to have occurred if the $\mathrm{OD}_{550}$ increased by more than $20 \%$. The data were fitted to the Ratkowsky square root temperature growth model (Ratkowsky et al., 1983) and cardinal temperatures were determined.

Whole-cell fatty acid analysis. Strains were cultivated on marine 2216 agar at $10^{\circ} \mathrm{C}$, harvested into a small amount of artificial seawater and then lyophilized using a vacuum freeze- drier (Dynavac). Whole-cell fatty acid profiles were quantitatively determined using GC and GC-MS procedures (Nichols et al., 1997). The geometry and position of double bonds in monounsaturated fatty acids was confirmed using dimethyldisulfide derivatization and GC-MS analysis (Nichols et al., 1986). The double bond positions are numbered from the methyl $(\omega)$ end of the fatty acid.

Genotypic analysis. Genomic DNA was extracted and purified using the procedure of Marmur \& Doty (1962). The G+C content was then determined from thermal denaturation profiles (Sly et al., 1986). The spectrophotometric renaturation rate kinetic procedure (Huss et al., 1983) was used to determine DNA-DNA reassociation values between genomic DNA of different strains. Genomic DNA was sheared to a mean size of $1 \mathrm{~kb}$ using sonication, dialysed overnight at $4^{\circ} \mathrm{C}$ in $1 \times \mathrm{SSC}$ buffer $(0 \cdot 15 \mathrm{M} \mathrm{NaCl}, 0 \cdot 015 \mathrm{M} \mathrm{Na}$ citrate, $\mathrm{pH} 7 \cdot 0)$ and adjusted in concentration to approximately $75 \mu \mathrm{g} \mathrm{ml}^{-1}$. Following denaturation of the DNA samples, $20 \times$ SSC was added to increase the total sodium concentration to $0.5 \mathrm{M}$; hybridization was then performed at the optimal temperature for renaturation $\left(T_{\text {or }}\right)$ which was $25^{\circ} \mathrm{C}$ below the DNA melting temperature and was calculated from the equation $T_{\text {or }}$ $\left({ }^{\circ} \mathrm{C}\right)=51.5+(0.41 \times \% \mathrm{G}+\mathrm{C})$. The decline in absorbance of DNA mixtures and control DNA samples over a $40 \mathrm{~min}$ period was used to calculate DNA hybridization values from the following equation DNA hybridization $(\%)=$ $(4 A B-A-B / 2 \sqrt{ }(A \times B)) \times 100$ (Huss et al., 1983), where $A$ and $B$ represent the changes in absorbance for the two DNA samples being compared and $A B$ represents the change in absorbance for equimolar mixtures of the two DNA samples. DNA hybridization values equal to or below $25 \%$ are considered to represent background hybridization and are thus not considered significant (Huss et al., 1983).

Phylogenetic analysis. The $16 \mathrm{~S}$ rRNA sequence for strains ACAM 624, ACAM 625, ACAM 623 ${ }^{\mathrm{T}}$ and ACAM 628 have been determined previously (Bowman et al., 1997b). GenBank accession numbers for these sequences and for reference sequences are shown in Fig. 3. Sequence data were manually aligned to various $16 \mathrm{~S}$ rRNA sequences of representatives of the family Flavobacteriaceae obtained from the GenBank nucleotide library. Software from PHYLIP version $3.57 \mathrm{c}$ (Felsenstein, 1993) was used to further analyse the sequence data set. DNADIST (using the maximum-likelihood option) was used to determine sequence similarities and NEIGHBOR (using the neighbourliness option) to create a phylogenetic tree. The $16 \mathrm{~S}$ rRNA sequence of Bacteroides fragilis was used as the outgroup for the phylogenetic tree.

\section{RESULTS}

\section{Cellular and colonial morphology}

The sea ice isolates (ACAM 623 ${ }^{\mathrm{T}}$, ACAM 624, ACAM 625, ACAM 626 and ACAM 628) examined in this study (Table 1) produced colonies on marine agar 2216 which were pigmented bright orange, elastic in consistency, circular and convex in shape with slightly spreading edges and $5-10 \mathrm{~mm}$ in diameter after $21 \mathrm{~d}$ incubation at $5^{\circ} \mathrm{C}$. Colonies could be lifted entirely from the surface of the medium with a loop. The strains were similar in terms of cellular morphology, occurring as filaments, rods and in older cultures as coccoidal bodies. In young cultures $(24-72 \mathrm{~h}$ ) filaments of indeterminate length were formed which slowly glided on R2A-seawater agar. In older cultures and in flask cultures during 
Table 1. Source of strains studied

\begin{tabular}{|lll|}
\hline Species/strain designation & Strain no.* & Isolation site \\
\hline Sea ice isolates: & & \\
651 & ACAM $623^{\mathrm{T}}$ & Sea ice, Prydz Bay, Antarctica \\
IC055 & ACAM 624 & Sea ice, Prydz bay, Antarctica \\
IC132 & ACAM 625 & Sea ice, Ellis Fjord, Antarctica \\
EFDMS10 & ACAM 626 & Sea ice, Ellis Fjord, Antarctica \\
IC168 & ACAM 628 & Sea ice, Long Fjord, Antarctica \\
Reference strains: & & \\
{$[$ Cytophaga $]$ latercula } & ACAM $539^{\mathrm{T}}$ & Aquarium outflow \\
{$[$ Cytophaga $]$ lytica } & ACAM $74^{\mathrm{T}}$ & Beach mud \\
{$[$ Cytophaga $]$ marinoflava } & ACAM $75^{\mathrm{T}}$ & Seawater \\
'Melosira-colonizing' strain & IC166 & Melosira sp., sea ice \\
{$[$ Cytophaga $]$ uliginosa } & ACAM $538^{\mathrm{T}}$ & Marine sediment \\
{$[$ Flavobacterium $]$ gondwanense } & ACAM $48^{\mathrm{T}}$ & Hypersaline lake \\
{$[$ Flavobacterium $]$ gondwanense } & ACAM 43 & Hypersaline lake \\
{$[$ Flavobacterium $]$ gondwanense } & ACAM 46 & Hypersaline lake \\
{$[$ Flavobacterium $]$ gondwanense } & ACAM 55 & Hypersaline lake \\
{$[$ Flavobacterium $]$ gondwanense } & ACAM 62 & Hypersaline lake \\
{$[$ Flavobacterium $]$ salegens } & ACAM $44^{\mathrm{T}}$ & Hypersaline lake \\
{$[$ Flexibacter $]$ maritimus } & NCIMB $2154^{\mathrm{T}}$ & Red sea bream \\
Psychroserpens burtonensis & ACAM $188^{\mathrm{T}}$ & Marine salinity lake \\
Gelidibacter algens & ACAM $536^{\mathrm{T}}$ & Sea ice \\
{$[$ Flectobacillus $]$ glomeratus } & ACAM $171^{\mathrm{T}}$ & Marine salinity lake \\
Polaribacter sp. & $23-P$ & Sea ice \\
Polaribacter sp. & IC054 & Sea ice \\
Polaribacter sp. & IC066 & Sea ice \\
\hline
\end{tabular}

*Abbreviations: ACAM, Australian Collection of Antarctic Micro-organisms, Antarctic CRC, University of Tasmania, Tasmania, Australia; ATCC, American Type Culture Collection, Rockville, MD, USA; NCIMB, National Collection of Industrial and Marine Bacteria, Aberdeen, UK.

exponential-phase growth, the filaments were generally shorter $(5-50 \mu \mathrm{m}$ in length, $0.4-1.5 \mu \mathrm{m}$ in width) with rod-shaped and coccoidal cells much more prevalent (Fig. 1a). Filaments were often coiled or twisted in a somewhat variable fashion (Fig. 1b).

\section{Physiology and metabolism}

Some physiological, biochemical and nutritional properties of the sea ice strains are shown in Table 2. The strains were strictly aerobic, seawater-requiring chemoheterotrophs which failed to grow in liquid media at temperatures higher than $20^{\circ} \mathrm{C}$. On solid medium several of the strains also failed to grow at $15^{\circ} \mathrm{C}$ while some grew poorly at $10^{\circ} \mathrm{C}$. The optimum growth temperature $\left(T_{\text {opt }}\right)$ in marine 2216 broth was estimated to be $12{ }^{\circ} \mathrm{C}$ for ACAM $623^{\mathrm{T}}$. The maximum growth temperature $\left(T_{\max }\right)$ was estimated to be about $19^{\circ} \mathrm{C}$ while the theoretical minimum growth temperature $\left(T_{\text {min }}\right)$ of ACAM $623^{\mathrm{T}}$ was estimated to be $-16^{\circ} \mathrm{C}$ (Fig. $2)$. The maximum specific growth rate $\left(\mu_{\max }\right)$ was $0.037 \mathrm{~h}^{-1}$.

The sea ice strains were stenohaline, exhibiting optimal growth in the presence of seawater. Many of the strains exhibited either poor or no growth when the seawater concentration was reduced to $50 \%$ or when increased to double strength. Little or no growth occurred when the medium was only supplemented with $\mathrm{NaCl}$ (at concentrations ranging from 2 to $5 \%$ ). The strains required yeast extract for growth in a chemically defined medium. The strains were unable to grow anaerobically either by fermentation or anaerobic respiration. Only oxidative acid production from carbohydrates was observed and in general these reactions were weak and slow, taking up to $10 \mathrm{~d}$ to form on Leifson's oxidation/fermentation $(\mathrm{O} / \mathrm{F})$ medium. The isolates were also able to hydrolyse starch, Tween 80 and DNA and were positive for catalase and cytochrome- $c$ oxidase activity (Table 2 ). The strains possessed alkaline phosphatase, $\alpha$-glucosidase and $\beta$-glucosidase activity, indicated by the hydrolysis of chromogenic substrates (Table 2).

\section{DNA base composition and DNA-DNA hybridization}

The strains had $\mathrm{G}+\mathrm{C}$ contents ranging from 32 to $33 \mathrm{~mol} \%$ (mean $32 \cdot 6 \pm 0 \cdot 6, n=5$ ). Strains ACAM $623^{\mathrm{T}}$, ACAM 624 and ACAM 625 shared high DNA-DNA reassociation levels ranging from 84 to $96 \%$ while exhibiting only low hybridization levels with [Flavobacterium] salegens ACAM $44^{\mathrm{T}}(8-12 \%)$, [Flavo- 

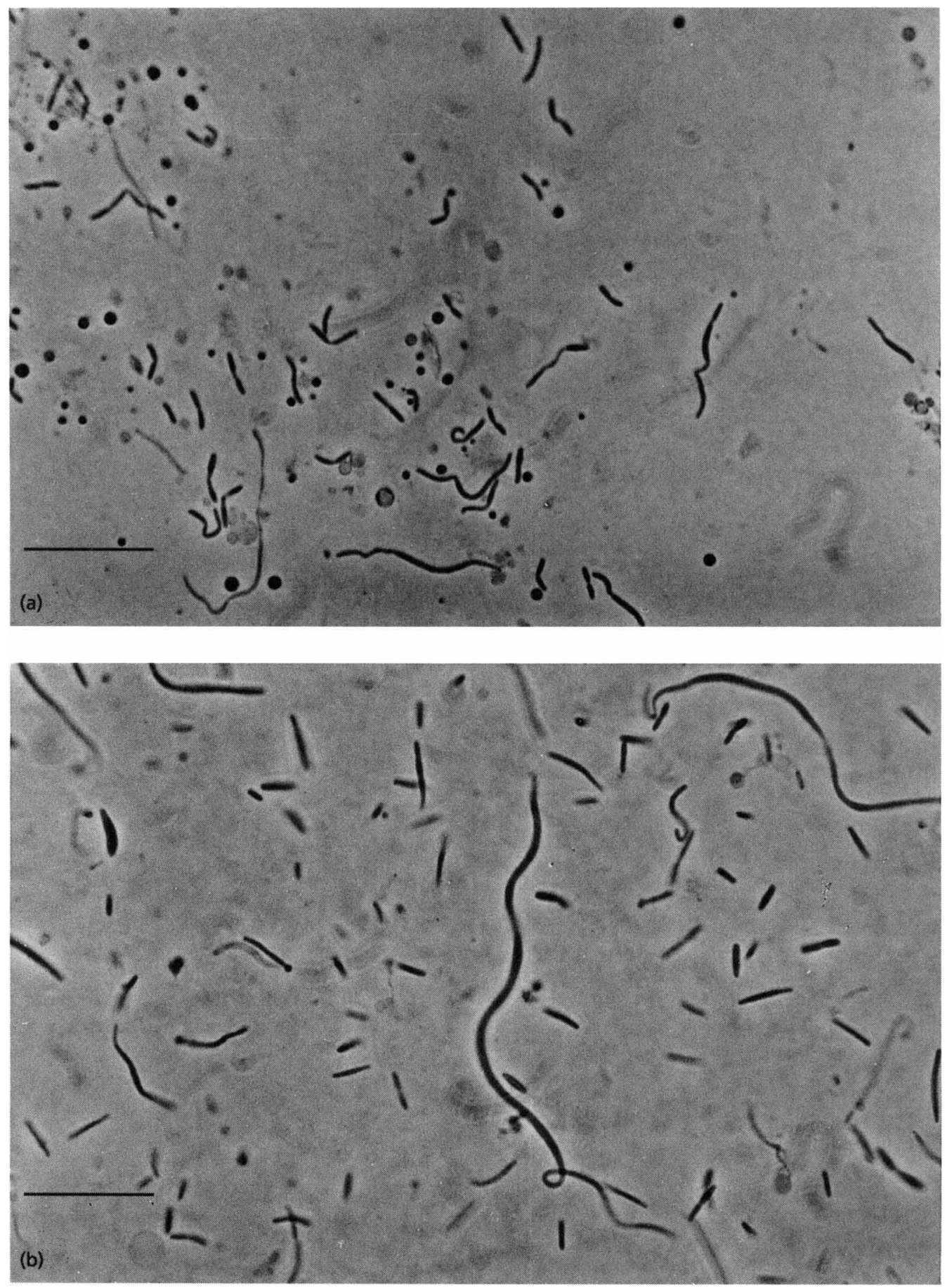

Fig. 1. (a) Phase-contrast micrograph of strain ACAM $623^{\top}$ grown on marine 2216 agar at $5{ }^{\circ} \mathrm{C}$ for $14 \mathrm{~d}$. (b) Phase-contrast micrograph of strain ACAM $623^{\top}$ grown in marine 2216 broth at $5^{\circ} \mathrm{C}$ for $7 \mathrm{~d}$. Bars, $10 \mu \mathrm{m}$.

bacterium] gondwanense ACAM $48^{\mathrm{T}}(17-28 \%)$ and [Cytophaga] latercula ACAM 539 ${ }^{\mathrm{T}}(11-21 \%)$.

\section{Fatty acid profiles}

The sea ice strains possessed very similar whole-cell fatty acid profiles, with the major constituents $(>5 \%$ of

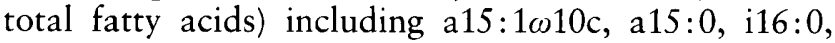

3-OH i16:0 and 3-OH a17:0 (Table 3). Straight-chain monounsaturated fatty acids were completely absent. However, the strains have the unusual capacity to synthesize PUFAs including 20:5 $03 \mathrm{c}(2-9 \%)$ and $20: 4 \omega 6 \mathrm{c}(1-3 \%)$. A number of reference flavobacterial species were also analysed for direct comparison as shown in Tables 1 and 3. The fatty acid profiles of a number of strains of [Flavobacterium] gondwanense 
Table 2. Phenotypic characteristics differentiating sea ice strains from [Flavobacterium] gondwanense

Data from Bowman et al. (1997b), Dobson et al. (1993) and this study. Abbreviations: + , test is positive for all strains; $v+$, test varies between strains, type strain is positive; $v-$, test varies between strains, type strain is negative; - , test is negative for all strains. Parentheses indicate a weak and/or delayed reaction. The following tests were positive for both species: production of catalase, cytochrome- $c$ oxidase, alkaline phosphatase, $\alpha$-glucosidase, $\beta$-glucosidase and acid from D-mannose; hydrolysis of Tween 80 , starch and DNA. The following tests were negative for all strains: hydrolysis of casein, agar, chitin, urate and xanthine; reduction of nitrate to nitrite; denitrification; production of hydrogen sulfide, lysine decarboxylase, ornithine decarboxylase, arginine dihydrolase, tryptophan deaminase, phenylalanine deaminase, $\alpha$-arabinosidase, $\alpha$ fucosidase, $\alpha$-galactosidase, $\beta$-galactosidase, streptococcal $\beta$-galactosidase, $\beta$-glucuronidase, $\alpha$ mannosidase; production of indole from tryptophan; production of acid from rhamnose, fructose, galactose, lactose, melibiose, raffinose, sucrose, trehalose, dextran, arabitol, adonitol, sorbitol, mannitol, inositol, $\mathrm{N}$-acetylglucosamine and chitin.

\begin{tabular}{|lcc|}
\hline Characteristic & $\begin{array}{c}\text { Psychroflexus } \\
\text { torquis }\end{array}$ & $\begin{array}{c}\text { [Flavobacterium } \\
\text { gondwanense }\end{array}$ \\
\hline No. of strains & 5 & 5 \\
Filaments $>100 \mu \mathrm{m}$ & + & - \\
Gliding motility & + & - \\
$T_{\min }\left({ }^{\circ} \mathrm{C}\right)$ & -16 & -5 \\
$T_{\text {opt }}\left({ }^{\circ} \mathrm{C}\right)$ & $10-15$ & $20-25$ \\
$T_{\max }\left({ }^{\circ} \mathrm{C}\right)$ & $15-20$ & 30 \\
Optimum salinity $(\mathrm{M} \mathrm{NaCl})$ & $0 \cdot 4$ & $1 \cdot 0$ \\
Salinity range $(\mathrm{M} \mathrm{NaCl})$ & $0 \cdot 25-0 \cdot 8$ & $0-3 \cdot 0$ \\
Yeast extract requirement & + & - \\
Hydrolysis of: & - & + \\
Aesculin & - & $\mathrm{v}+$ \\
Urea & - & $\mathrm{v}-$ \\
Gelatin & $(\mathrm{v}+)$ & + \\
Production of acid from: & - & + \\
D-Glucose, maltose & $\mathrm{v}-$ & 36 \\
L-Arabinose, D-xylose, cellobiose & $32-33$ & \\
Glycerol & & \\
DNA G + C content (mol \%) & & \\
\hline
\end{tabular}

were similar to the profiles of the sea ice isolates but differed in that PUFAs were absent. In addition, the sea ice strains contained higher ratios of anteiso- to isobranched fatty acids $(2 \cdot 5: 1)$ while for [Flavobacterium] gondwanense these classes of fatty acids occurred in approximately equimolar ratios.

\section{Phylogeny}

The phylogenetic relationships of four representatives of the sea ice strains $\left(A C A M \quad 623^{\mathrm{T}}\right.$, ACAM 624, ACAM 625 and ACAM 628) were examined by distance and maximum-likelihood methods. 16S rRNA sequences were 1439-1455 nt in length and extended from nucleotide positions 35 to 1508 (Escherichia coli equivalent). The sequences for ACAM $623^{\mathrm{T}}$, ACAM 624 and ACAM 625 were identical while the similarity of these strains to ACAM 625 was $99 \cdot 1 \%$. [Flavobacterium] gondwanense ACAM $48^{\mathrm{T}}$ was found to be closely related to the sea ice strains with a sequence similarity of $97 \cdot 8-98 \cdot 1 \%$ (Table 1 ). Together the sea ice strains and [Flavobacterium] gondwanense formed a distinct branch in the Family Flavobacteriaceae (Bernardet et al., 1996) (Fig. 3). The closest relatives were [Flavobacterium] salegens and [Cytophaga] latercula which were approximately equidistant from [Flavobacterium] gondwanense and the sea ice strains.

\section{DISCUSSION}

Fatty acid profiles (Table 3), phylogenetic data (Fig. 3) and phenotypic data (Table 4) support a close relationship between the sea ice isolates and the moderately halophilic species [Flavobacterium] gondwanense. The major differences between the groups are ecophysiological. The sea ice strains are psychrophilic, slow-growing rod-like to coiled filamentous cells capable of gliding motility and with fastidious growth requirements. So far this group has only been isolated from sea ice (Bowman et al., 1997a, b) and so far have not been isolated from under-ice seawater samples (Bowman et al., 1997b) or from the marine-salinity 


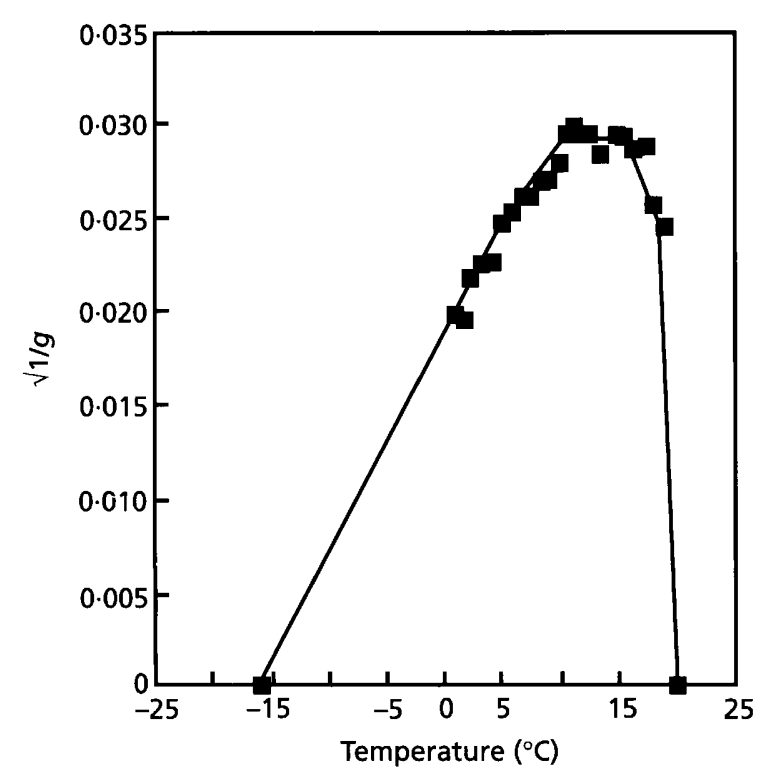

Fig. 2. Temperature/growth rate response curve of strain ACAM $623^{\top}$ based on the square root growth model of Ratkowsky et al. (1983).

Burton Lake which has a noticeably enriched psychrophilic population (Franzmann et al., 1990). By comparison [Flavobacterium] gondwanense is psychrotrophic, moderately halophilic, non-motile and has a non-exacting nutrient requirement (Dobson et al., 1993; this study). [Flavobacterium] gondwanense has been isolated and observed by indirect immunofluoresence in the upper layers of a number of Antarctic hypersaline lakes (James et al., 1994) but so far has not been isolated from or detected in Antarctic marine salinity sites (Bowman et al., 1997a, b).

Both the sea ice strains and [Flavobacterium] gondwanense have similar fatty acid profiles, differing only in that [Flavobacterium] gondwanense lacks PUFAs and has a more even iso-to anteiso-branched fatty acid ratio. The fatty acid profiles of the two taxa differ considerably from other phylogenetically related flavobacteria (Table 3). The synthesis of PUFAs and high levels of anteiso-branched fatty acids in the sea ice strains represents a higher degree of cold adaptation owing to the continually low sympagic in situ temperatures, typically between -1 and $-15^{\circ} \mathrm{C}$. By comparison the oxic layer temperatures of hypersaline lakes which [Flavobacterium] gondwanense is known to inhabit are often higher, ranging from -2 to $12^{\circ} \mathrm{C}$ (summer temperature range; James et al., 1994). It is known that both PUFAs and branched fatty acids tend to reduce lipid bilayer viscosity (Kaneda, 1991). The sea ice strains are the first bacterial strains found conclusively to contain arachidonic acid, possibly as a byproduct of eicosapentaenoic acid synthesis. Studies using ${ }^{14} \mathrm{C}$-labelling have revealed arachidonic acid as a transient precursor in the synthesis of eicosapentaenoic acid in Vibrio-like strains (Iwanami et al., 1995). Amongst the flavobacteria, PUFA synthesis has only been observed previously in [Flexibacter] polymorphus (Johns \& Perry, 1977) which contains eicosapentaenoic acid which in turn was believed to have a role in promoting gliding motility. [Flexibacter] polymorphus is phylogenetically remote from the sea ice strain groups and has a very different fatty acid pattern (Table 3 ). Bacterial $\omega 3$ (but not $\omega 6$ ) PUFA synthesis has also been found to occur in species of the genera Shewanella and Colwellia and in the species [Vibrio] marinus (DeLong et al., 1997). No information exists on how bacteria have obtained the genes for PUFA synthesis but it is known that phytoplankton able to form $\omega 3$ PUFA use a variety of different synthetic pathways (Sprecher et al., 1995). Studies currently examining the specific synthetic pathways of PUFA formation in bacteria may provide further insight into the development of this unusual characteristic.

Overall, the similar fatty acid profile and close phylogenetic association provide evidence that the sea ice strains and [Flavobacterium] gondwanense belong to a group distinct from other members of the family Flavobacteriaceae. The closest relatives, [Flavobacterium] salegens and [Cytophaga] latercula, each possess fatty acid profiles quite different from each other and distinct from [Flavobacterium] gondwanense and the sea ice strains, thus suggesting that these species each may represent a distinct genus. On the basis of polyphasic taxonomic data presented in this study, the sea ice strains clearly represent a novel taxonomic group equivalent to a new genus, Psychroflexus gen. nov. The closely related [Flavobacterium] gondwanense also belongs to this new group but represents a distinct species. Thus, the sea ice strains constitute a new species, Psychroflexus torquis sp. nov., while [Flavobacterium] gondwanense becomes Psychroflexus gondwanense gen. nov., comb. nov.

\section{Description of Psychroflexus gen. nov.}

Psychroflexus (Psy.chro'flex.us. Gr. adj. psychros cold; L. masc. n. flexus bend, curve; M. L. masc. n. Psychroflexus cold bend).

Gram-negative. Cellular morphology ranges from rodlike cells to coiled filaments and filaments of indeterminate length. Coccoid cells are present in older cultures. Ring-shaped cells and gas vesicles are not formed. Resting stages are absent. Either non-motile or motile via slow gliding motility. Orange carotenoid-like pigments are formed. Flexirubin pigments are absent. Strictly aerobic chemoheterotroph. Psychrophilic or psychrotrophic. Slightly or moderately halophilic. Major cellular fatty acids are a15:0, a15:10 $\omega 10 \mathrm{c}, \mathrm{i} 16: 0$, 3-OH i16:0 and 3-OH a17:0. Major respiratory quinone is menaquinone-6 (determined for Psychroflexus gondwanense only). G $+\mathrm{C}$ content $32-36 \mathrm{~mol} \%$ (determined by thermal denaturation). Member of the family Flavobacteriaceae. Genus contains two species, Psychroflexus gondwanense and Psychroflexus torquis. Type species is Psychroflexus torquis. 
Table 3. Whole-cell fatty acid profiles of PUFA-containing sea ice isolates compared with other members of the Flavobacteriaceae and [Flexibacter] polymorphus

All values are means $\pm \mathrm{SD}$ (in parentheses); $\mathrm{TR}$, trace amount. Bold type indicates predominating fatty acids.

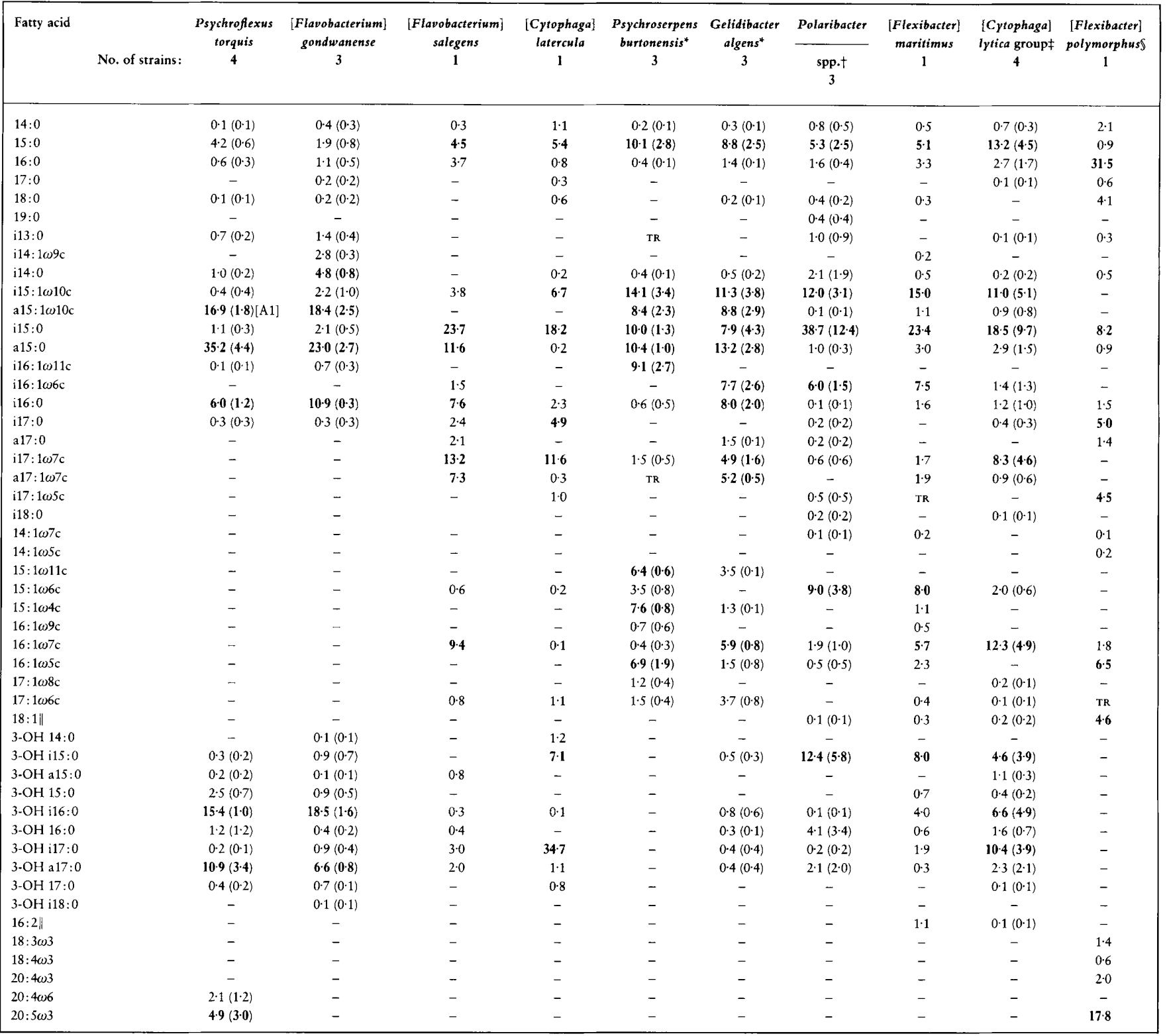

"Data from Bowman et al. (1997c).

† Strains of Polaribacter spp. include [Flectobacillus] glomeratus, gas vacuolate strain 23-P and sea ice strains IC054 and IC066.

$\ddagger$ Strains in the [Cytophaga] lytica group include [Cytophaga] lytica, [Cytophaga] marinoflava, [Cytophaga] uliginosa and 'Melosiracolonizing' strain IC166.

\$Data from Johns \& Perry (1977).

|| Double bond positions in 18:1 fatty acids were either $\omega 7 \mathrm{c}$ or $\omega 9 \mathrm{c}$, while double bond positions in 16:2 fatty acids were not determined.

Description of Psychroflexus torquis gen. nov., sp. nov.

Psychroflexus torquis (tor'quis. L. masc. n. torquis something twisted, referring to coiling of filaments).

On solid media cells range from filaments of indeterminate length in very young cultures, which slowly glide, to coccoid bodies in older cultures. On solid media and when in liquid media rod-like to filamentous cells (5-50 $\mu \mathrm{m}$ in length, $0.4-1.5 \mu \mathrm{m}$ in width) are formed. Filamentous cells often appear coiled. The incidence of coccoid bodies increases in older cultures. Stenohaline. Requires seawater for growth. Psychrophilic, with growth occurring at $0^{\circ} \mathrm{C}$ and optimal growth occurring at $10-15^{\circ} \mathrm{C}$ in liquid media. No growth occurs at temperatures at or above $20^{\circ} \mathrm{C}$ in liquid media. Requires 


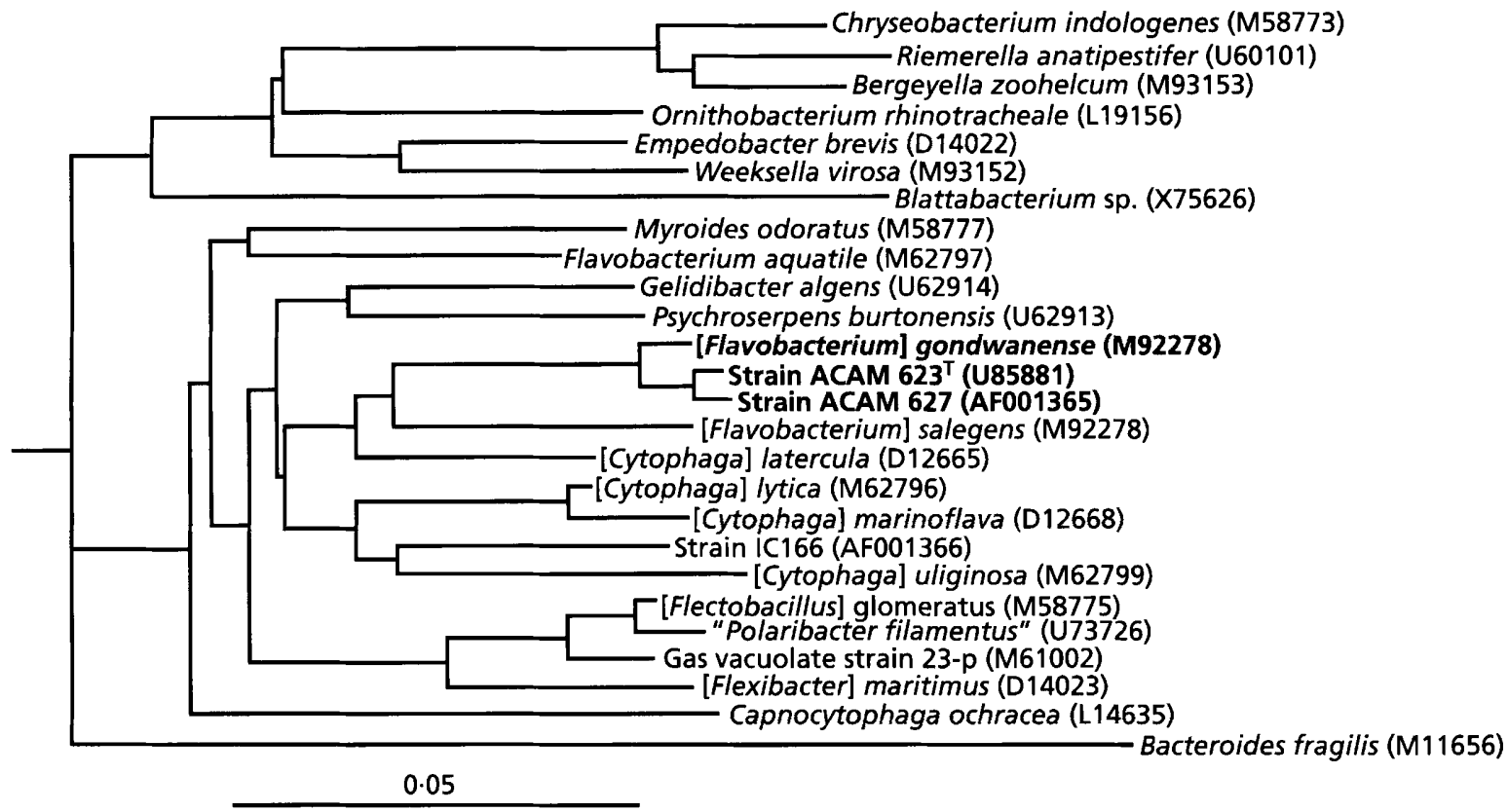

Fig. 3. Phylogenetic tree showing the relationship of Psychroflexus torquis strains to other members of the family Flavobacteriaceae. The topology of the tree is based on maximum-likelihood distances. GenBank accession numbers are shown in parentheses. Bar, sequence dissimilarity value of $5 \%$.

Table 4. Phenotypic characteristics differentiating Psychroflexus species from other members of the Flavobacteriaceae

Abbreviations: - , negative; +, positive; V, variable; O, orange; $\mathrm{Y}$, yellow; $\mathrm{R}$, red; $\mathrm{SH}$, slightly halophilic; $\mathrm{MH}$, moderately halophilic.

\begin{tabular}{|c|c|c|c|c|c|c|c|c|c|c|c|}
\hline \multirow[t]{2}{*}{ Species } & \multirow{2}{*}{$\begin{array}{l}\text { Gliding } \\
\text { motility }\end{array}$} & \multirow[t]{2}{*}{ Pigment } & \multirow{2}{*}{$\begin{array}{c}\text { Growth at } \\
25^{\circ} \mathrm{C}\end{array}$} & \multirow{2}{*}{$\begin{array}{c}\text { Salinity } \\
\text { requirement }\end{array}$} & \multirow{2}{*}{$\begin{array}{l}\text { Yeast extract } \\
\text { requirement }\end{array}$} & \multirow{2}{*}{$\begin{array}{c}\text { Carbohydrate } \\
\text { utilization }\end{array}$} & \multicolumn{2}{|c|}{ Hydrolysis } & \multirow{2}{*}{$\begin{array}{c}\beta \text {-Galactosidase } \\
\text { activity }\end{array}$} & \multirow{2}{*}{$\begin{array}{l}\text { Nitrate } \\
\text { reduction }\end{array}$} & \multirow{2}{*}{$\begin{array}{c}\mathrm{G}+\mathrm{C} \\
(\mathrm{mol} \%)\end{array}$} \\
\hline & & & & & & & Starch & Agar & & & \\
\hline Psychroflexus torquis & + & $\mathrm{O}$ & - & SH & + & + & + & - & - & - & $32-33$ \\
\hline Psychroflexus gondwanense & - & 0 & + & MH & - & + & + & - & - & - & 36 \\
\hline [Flavobacterium] salegens & - & $\mathrm{Y}$ & + & MH & - & + & + & - & + & + & $37-38$ \\
\hline [Cytophaga] latercula & - & $\mathrm{O}-\mathrm{R}$ & + & $\mathrm{SH}$ & - & + & - & + & + & - & 32 \\
\hline Psychroserpens burtonensis & - & $\mathrm{Y}$ & - & $\mathrm{SH}$ & + & - & - & - & $\mathrm{V}$ & - & $27-29$ \\
\hline Gelidibacter algens & + & $\mathrm{Y}$ & $\mathrm{v}$ & $\mathrm{SH}$ & - & + & + & - & - & - & $36-38$ \\
\hline $\begin{array}{l}\text { Polaribacter }[\text { Flectobacillus] } \\
\text { glomeratus group }\end{array}$ & - & $\mathrm{O}$ & - & SH & + & + & v & - & $\mathrm{V}$ & - & $31-34$ \\
\hline [Flexibacter] maritimus group* & + & $\mathrm{Y}$ & + & $\mathrm{SH}$ & + & - & - & - & - & + & $29-32$ \\
\hline [Cytophaga] lytica group $\dagger$ & + & $O-Y$ & + & $\mathrm{SH}$ & - & + & + & $\mathrm{v}$ & $\mathrm{V}$ & $\mathrm{V}$ & $32-42$ \\
\hline
\end{tabular}

*Includes [Flexibacter] maritimus and [Flexibacter] ovolyticus.

†Includes [Cytophaga] lytica, [Cytophaga] marinoflava, [Cytophaga] uliginosa and 'Melosira-colonizing' strain IC166. [Cytophaga] uliginosa forms flexirubin.

yeast extract for growth in chemically defined media. Catalase- and oxidase-positive. Alkaline phosphatase, $\alpha$-glucosidase and $\beta$-glucosidase activity present. Gelatin, Tween 80, starch and DNA degraded. Acid formation from carbohydrates is slow and delayed in Leifson's $\mathrm{O} / \mathrm{F}$ medium. Acid is formed by most strains from D-glucose, D-mannose and maltose. Some strains can also form acid from glycerol. Other traits are shown in Table 2. Contains polyunsaturated fatty acids $20: 503$ and $20: 4 \omega 6$. G $+C$ content $32-33 \mathrm{~mol} \%$ (determined by thermal denaturation). Colonies on seawater medium are circular, raised convex with slightly spreading edges, an elastic-gummy consistency, 5-10 mm diameter after $21 \mathrm{~d}$ incubation and pigmented bright orange. Type strain is ACAM $623^{\mathrm{T}}$ isolated from sea ice collected from Prydz Bay, Vestfold Hills, Antarctica.

\section{Description of Psychroflexus gondwanense (Dobson et al. 1993) gen. nov., comb. nov.}

The description is identical to that given for Flavobacterium gondwanense by Dobson et al. (1993). Type strain is ACAM $48^{\mathrm{T}}$, isolated from Organic Lake, Vestfold Hills, Antarctica. 


\section{ACKNOWLEDGEMENTS}

This research was supported by grants from the Australian Research Council (grant no. A19602517) and Antarctic Science Advisory Committee (grant no. 1012). We would like to thank Professor Jim Staley (University of Washington, Seattle) for strain 23-P and Professor Hans Trüper (Bonn University, Germany) for advice with the Latin names.

\section{REFERENCES}

Bernardet, J.-F., Segers, P., Vancanneyt, M., Berthe, F., Kersters, K. \& Vandamme, P. (1996). Cutting a gordian knot: emended classification and description of the genus Flavobacterium, emended description of the Family Flavobacteriaceae and proposal of Flavobacterium hydatis nom. nov. (basonym, Cytophaga aquatilis Strohl and Tait 1978). Int J Syst Bacteriol 46, 128-148.

Bowman, J. P., Brown, M. V. \& Nichols, D. S. (1997a). Biodiversity and ecophysiology of bacteria associated with Antarctic sea ice. Antarct Sci 9, 134-142.

Bowman, J. P., McCammon, S. A., Brown, M. V., Nichols, D. S. \& McMeekin, T. A. (1997b). Diversity and association of psychrophilic bacteria in Antarctic sea ice. Appl Environ Microbiol 63, 3068-3078.

Bowman, J. P., McCammon, S. A., Brown, J. L., Nichols, P. D. \& McMeekin, T. A. (1997c). Psychroserpens burtonensis gen. nov., sp. nov., and Gelidibacter algens gen. nov., sp. nov., psychrophilic bacteria from Antarctic lacustrine and sea ice habitats. Int I Syst Microbiol 47, 670-677.

Christian, J. R. \& Karl, D. M. (1995). Bacterial ectoenzymes in marine waters: activity ratios and temperature responses in three oceanographic provinces. Limnol Oceanogr 40, 1042-1049.

Delille, D. (1996). Biodiversity and function of bacteria in the Southern Ocean. Biodivers Conserv 5, 1505-1523.

DeLong, E. F., Franks, D. G. \& Yayanos, A. A. (1997). Evolutionary relationships of cultivated psychrophilic and barophilic deep-sea bacteria. Appl Environ Microbiol 63, 2105-2108.

Dobson, S. J., Colwell, R. R., McMeekin, T. A. \& Franzmann, P. D. (1993). Direct sequencing of the polymerase chain reactionamplified 16S rRNA gene of Flavobacterium gondwanense sp. nov. and Flavobacterium salegens sp. nov., two new species from a hypersaline Antarctic lake. Int J Syst Bacteriol 43, 77-83.

Felsenstein, J. (1993). PHYLIP (phylogeny inference package), version 3.57c. University of Washington, Seattle.

Franzmann, P. D., Deprez, P. P., McGuire, A. J., McMeekin, T. A. \& Burton, H. R. (1990). The heterotrophic bacterial microbiota of Burton Lake, Antarctica. Polar Biol 10, 261-264.

Gosink, J. J. \& Staley, J. T. (1995). Biodiversity of gas vacuolate bacteria from Antarctic sea ice and water. Appl Environ Microbiol 61, 3486-3489.

Gosink, J. J., Woese, C. R. \& Staley, J. T. (1998). Polaribacter gen. nov., with three new species, $P$. irgensii sp. nov., $P$. franzmannii sp. nov. and $P$. filamentus sp. nov., gas vacuolate polar marine bacteria of the Cytophaga-Flavobacterium-Bacteroides group and reclassification of 'Flectobacillus glomeratus' as Polaribacter glomeratus comb. nov. Int J Syst Bacteriol 48, 223-235.

Helmke, E. \& Weyland, H. (1995). Bacteria in sea ice and underlying water of the eastern Weddell Sea in midwinter. Mar Ecol Prog Ser 117, 269-287.

Huss, V. A. R., Festl, H. \& Schleifer, K.-H. (1983). Studies on the spectrophotometric determination of DNA hybridization from renaturation rates. Syst Appl Microbiol 4, 184-192.
Irgens, R., Gosink, J. J. \& Staley, J. T. (1996). Polaromonas vacuolata gen. nov., sp. nov., a psychrophilic, marine, gas vacuolate bacterium from Antarctica. Int J Syst Bacteriol 46, 822-826.

Iwanami, H., Yamaguchi, T. \& Takeuchi, M. (1995). Fatty acid metabolism in bacteria that produce eicosapentaenoic acid isolated from sea urchin Strongylocentrotus nudus. Nippon Suisan Gakkaishi 61, 205-210.

James, S. R., Burton, H. R., McMeekin, T. A. \& Mancuso, C. A. (1994). Seasonal abundance of Halomonas meridiana, Halomonas subglaciescola, Flavobacterium gondwanense and Flavobacterium salegens. Antarct Sci 6, 325-332.

Johns, R. B. \& Perry, G. J. (1977). Lipids of the marine bacterium Flexibacter polymorphus. Arch Microbiol 114, 267-271.

Kaneda, T. (1991). Iso- and anteiso-fatty acids in bacteria: biosynthesis, function and taxonomic significance. Microbiol Rev 55, 288-302.

Malinsky-Rushansky, N. Z. \& Legrand, C. (1996). Excretion of dissolved organic carbon by phytoplankton of different sizes and subsequent bacterial uptake. Mar Ecol Prog Ser 132, 249-255.

Marmur, J. \& Doty, P. (1962). Determination of the base composition of deoxyribonucleic acid from its thermal denaturation temperature. J Mol Biol 5, 109-118.

Nichols, D. S., Brown, J. L., Nichols, P. D. \& McMeekin, T. A. (1997). Production of eicosapentaenoic acid and arachidonic acids by an Antarctic bacterium: response to growth temperature. FEMS Microbiol Lett 152, 349-354.

Nichols, P. D., Guckert, J. B. \& White, D. C. (1986). Determination of monounsaturated fatty acid double-bond position and geometry for microbial monocultures and complex consortia by capillary GC-MS of their dimethyldisulphide adducts. J Microbiol Methods 5, 49-55.

Palmisano, A. C. \& Garrison, D. L. (1993). Microorganisms in Antarctic sea ice. In Antarctic Microbiology, pp. 167-218. Edited by E. I. Friedmann. New York: Wiley-Liss.

Priddle, J., Leakey, R. J. G., Archer, S. D. \& Murphy, E. J. (1996). Eukaryotic microbiota in the surface waters and sea ice of the Southern Ocean: aspects of physiology, ecology and biodiversity in a 'two-phase' ecosystem. Biodivers Conserv 5, 1473-1504.

Ratkowsky, D. A., Lowry, R. K., McMeekin, T. A., Stokes, A. N. \& Chandler, R. E. (1983). Model for bacterial growth throughout the entire biokinetic range. J Bacteriol 154, 1222-1226.

Sly, L. I., Blackall, L. L., Kraat, P. C., Tian-Shen, T. \& Sangkhobol, V. (1986). The use of second derivative plots for the determination of mol \% guanine plus cytosine of DNA by the thermal denaturation method. J Microbiol Methods 5, 139-156.

Smibert, R. M. \& Krieg, N. R. (1994). Phenotypic characterization. In Methods for General and Molecular Microbiology, pp. 611-654. Edited by P. Gerhardt, R. G. Murray, W. A. Wood \& N. R. Krieg. Washington, DC: American Society for Microbiology.

Sprecher, H., Luthria, D. L., Mohammed, B. S. \& Baykousheva, S. P. (1995). Re-evaluation of the pathways for the biosynthesis of polyunsaturated fatty acids. J Lipid Res 36, 2471-2477.

Sullivan, C. W. \& Palmisano, A. C. (1984). Sea ice microbial communities: distribution, abundance and diversity of ice bacteria in McMurdo Sound, Antarctica, in 1980. Appl Environ Microbiol 47, 788-795.

Received 1 September 1997; revised 19 January 1998; accepted 25 February 1998. 